Article

\title{
The Effect of Emission Inventory on Modelling of Seasonal Exposure Metrics of Particulate Matter and Ozone with the WRF-Chem Model for Poland
}

\author{
Maciej Kryza ${ }^{1, * \mathbb{C}}$, Małgorzata Werner ${ }^{1}{ }^{\mathbb{C}}$, Justyna Dudek ${ }^{1}$ and Anthony James Dore ${ }^{2}$ \\ 1 Department of Climatology and Atmosphere Protection, University of Wrocław, 50-137 Wroclaw, Poland; \\ malgorzta.werner@uwr.edu.pl (M.W.); justyna.dudek@uwr.edu.pl (J.D.) \\ 2 Centre for Ecology \& Hydrology (Edinburgh), Penicuik EH26 0QB, UK; todo@ceh.ac.uk \\ * Correspondence: maciej.kryza@uwr.edu.pl
}

Received: 1 June 2020; Accepted: 30 June 2020; Published: 4 July 2020

\begin{abstract}
In Poland, high concentrations of particulate matter (with a diameter smaller than 2.5 or $10 \mu \mathrm{m})$ exceeding the WHO threshold values are often measured in winter, while ozone $\left(\mathrm{O}_{3}\right)$ concentrations are high in spring. In winter high PM2.5 and PM10 concentrations are linked to high residential combustion and road transport. The main objective of this study was to assess performance of the Weather Research and Forecasting model with Chemistry (WRF-Chem) model in reproducing observations for a period of 2017-2018 covering various meteorological conditions. We compare modelled and observed exposure metrics for PM2.5, PM10 and $\mathrm{O}_{3}$ for two sets of the WRF-Chem model runs: with coarse and fine resolution emission inventory (European Monitoring and Evaluation Programme (EMEP) and Chief Inspectorate of Environmental Protection (CIEP), respectively). CIEP run reduces the negative bias of PM2.5 and PM10 and improves the model performance for number of days with exceedance of WHO (World Health Organization) threshold for PM2.5 and PM10 24-h mean concentration. High resolution emission inventory for primary aerosols helps to better distinguish polluted urban areas from non-urban ones. There are no large differences for the model performance for $\mathrm{O}_{3}$ and secondary inorganic aerosols, and high-resolution emission inventory does not improve the results in terms of 8-h rolling mean concentrations of ozone.
\end{abstract}

Keywords: WRF-Chem; ozone; particulate matter; Poland

\section{Introduction}

Air quality is one of the most serious environmental issues with adverse impacts on population health and life quality. A report published by WHO estimates that 3.7 million premature deaths were caused by exposure to polluted air worldwide [1]. The pollutants with the most severe impact on population health are particulate matter (PM2.5 and PM10), ozone $\left(\mathrm{O}_{3}\right)$ and nitrogen dioxide $\left(\mathrm{NO}_{2}\right)$. For these key pollutants, there are concentration-response functions (CRFs) which are included in cost-benefit analysis [2]. CRFs link the concentration of the key pollutants with health effects, including mortality, hospital admissions or incidence of asthma symptoms. In addition to the health-related effects, low air quality also has also other impact, e.g., deteriorating tourist attractiveness [3].

Poland is one of the European countries with the most polluted air. Recently, a study of air pollution [4] estimated that the reduction of mean life expectancy in Poland, due to air pollution, is 2.8 years, compared to 2.2 for Europe. The main problem is related to high concentrations of particulate matter in winter. This is caused by emission from residential combustion during the heating season and wide consumption of low-quality hard coal in this emission sector [5-9]. A large number of days with exceedances of the WHO recommended 24-h mean concentrations of PM2.5 (25 $\left.\mathrm{gg} \mathrm{m}^{-3}\right)$ 
and PM10 (50 $\left.\mu \mathrm{g} \mathrm{m}^{-3}\right)$ was reported for recent years in many publications, e.g., for Poznań [10,11], Gdynia [6], the Upper Silesia and Kraków area [12] or Lower Silesia [13] and Wrocław [14]. According to [15] ambitious and early actions targeting solid fuel heating installations in the residential sector, supported by financial mechanisms will bring substantial reductions of primary PM2.5 emissions. According to the EMEP WebDab emission inventory, particulate matter emission will drop 30\% in Poland by 2030, as a result of national emission abatements policy and shifts between energy sectors [16].

Ground-level ozone is a secondary pollutant produced by photochemical reactions involving $\mathrm{NO}_{\mathrm{x}}$, $\mathrm{CO}$ and Volatile Organic Compounds (VOCs). A clear relation between high ozone concentrations and mortality or daily admission for chronic obstructive pulmonary disease was shown by $[17,18]$. The episodes of high concentrations are strongly related to meteorological conditions [19]. High air temperatures, enhanced solar irradiance and calm wind are favorable for formation of high-ozone episodes. In the spring and summer periods, high concentrations of $\mathrm{O}_{3}$ are observed over Poland [20,21]. Several examples of heat waves with high $\mathrm{O}_{3}$ concentrations were described e.g., by [22].

Chemistry transport models (CTMs) are often used to provide information on pollutant concentration for health-related studies. They have the advantage of providing more detailed national spatial coverage than is usually possible with monitoring data alone. Within the AQMEII project, detailed evaluation of several CTMs was presented for ozone and particulate matter, for Europe and North America. The authors in [23] have shown that the Community Multiscale Air Quality model (CMAQ) underestimates ozone concentrations in Europe in spring and summer. Similar findings were presented by [22] for high ozone episode observed in July 2006 modelled with Global Environmental Multiscale - Air Quality model (GEM-AQ). PM2.5 concentrations are also underestimated, especially in winter, and this underestimation reached 55\% [23]. Strong underestimation of PM2.5 and PM10 concentration in Europe modelled with various models was also presented by [24]. For PM2.5 and PM10 the models, on average, underestimated observed values up to $57 \%$. Rural stations were less affected by this bias if compared to urban. In [25], the authors conclude that underestimation of PM2.5 has the key impact on application of the CTMs on epidemiological studies, as PM2.5 is the main driver for health impacts in Europe.

In this work we have applied the online integrated Weather Research and Forecasting model with Chemistry [26] to calculate hourly concentrations of PM2.5, PM10 and $\mathrm{O}_{3}$ for Poland for two years: 2017 and 2018. The model was run twice, using two separate emission inventories different in terms of their source spatial resolution. Next, we have compared the model results with hourly measurements of PM2.5, PM10 and $\mathrm{O}_{3}$. Further, we have calculated pollutant exposure metrics, suggested by the HRAPIE project [2] using both the model results and measurements data, and evaluated the model skills in reproducing these metrics. The pollutant metrics included are 24-h mean concentrations of PM2.5 and PM10, 8-h rolling mean for $\mathrm{O}_{3}$, and number of days with WHO threshold values exceeded. The main aim of this paper is to summarize the Weather Research and Forecasting with Chemistry (WRF-Chem) model capabilities in reproducing not only hourly observations, but also these health-related metrices for a long time period covering various meteorological conditions. Further, we investigate the impact of two different emission inventories: European-wide EMEP WebDab and national emission inventory developed in Poland by Chief Inspectorate of Environmental Protection (CIEP) on the model performance in terms of pollutant exposure metrics.

\section{Materials and Methods}

\subsection{WRF-Chem Model Configuration}

The Weather Research and Forecasting model with Chemistry (WRF-Chem) version 3.9.1 was used to calculate the spatial and temporal distribution of air pollutants concentration, including PM2.5, PM10 and ozone $\left(\mathrm{O}_{3}\right)$. WRF-Chem is an "online" model as chemistry and meteorology are fully 
coupled, i.e., both components use the same transport scheme, horizontal and vertical grid, time step and physical parameterization for subgrid-scale transport [26].

The model was run with two one-way nested domains. The outer domain covers Europe at a $12 \mathrm{~km} \times 12 \mathrm{~km}$ grid $(160 \times 160$ grids in east-west and north-south directions) and the inner domain is focused on Poland at $4 \mathrm{~km} \times 4 \mathrm{~km}$ resolution $(241 \times 241$ grids). We used 35 vertical levels with the lowest layer's top at about $30 \mathrm{~m}$. Physical parameters used for the simulations are as previously described [27]. It includes the Noah Land Surface Model [28], YSU boundary layer physics [29], RRTMG long and short wave radiation scheme [30], Grell 3D parameterization with radiation feedback and shallow convection and Morrison 2-moments microphysics scheme [31]. The simulations were driven by the NCEP final analysis, available every $6 \mathrm{~h}$, with $1^{\circ} \times 1^{\circ}$ spatial resolution. We used the Regional Atmospheric Chemistry Mechanism (RACM) for the gas phase chemistry with the Modal Aerosol Dynamics Model for Europe (MADE) for the inorganic fraction and the VBS (Volatility Base Set) for the carbonaceous secondary fraction [32]. According to our knowledge, this is the first time that these chemical and aerosols schemes were used together for this area of Poland that is characterized by a large share of emission from residential coal combustion (46\% of PM2.5 and PM10 is emitted from this sector; road transport is responsible for 10 and 7\%, respectively).

The model was run separately for two years: 2017 and 2018. For each year, the model run began on December $25^{\text {th }}$ of the previous year of the simulation, and the first seven days were treated as a spin-up time and were not considered in this study.

\subsection{Model Runs and Emission Inventories Used}

For each year, two simulations with different emission databases were run:

- $\quad$ EMEP run-for both domains (d01 and d02) we applied anthropogenic emission of $\mathrm{NO}_{2}, \mathrm{NH}_{3}$, $\mathrm{SO}_{2}$, primary PM2.5, primary PM10, $\mathrm{CO}$ and NMVOC from the EMEP WebDab database (https://www.ceip.at/webdab_emepdatabase/) available at $0.1^{\circ} \times 0.1^{\circ}$ spatial resolution.

- CIEP run-for d01 (and d02 outside of Poland) we used the same emission as for the EMEP run. For Poland, SNAP sector 2 (non-industrial combustion) and SNAP sector 7 (road transport) were replaced by emission provided by the Chief Inspectorate for Environmental Protection available at $1 \mathrm{~km} \times 1 \mathrm{~km}$.

A similar approach was earlier applied by [33], but the TNO MACC III (Monitoring Atmospheric Composition and Climate-III) emission database [34] was used as an input to the EMEP4PL model, with source spatial resolution of $1 / 8^{\circ} \times 1 / 16^{\circ}$. The change in emission between the EMEP and CIEP runs are significant, and are summarized for NMVOC, $\mathrm{NO}_{2}, \mathrm{PM} 10$ and PM2.5 in Table 1. Generally, the CIEP emissions are higher for PM2.5 and PM10, both for residential combustion $(70 \%$ and $43 \%$, respectively for PM2.5 and PM10) and road transport (83\% and 72\%, respectively). For $\mathrm{NO}_{\mathrm{x}}, \mathrm{CIEP}$ SNAP sector 2 is $23 \%$ lower if compared to the coarse resolution EMEP. NOx emission from road transport is $56 \%$ higher for CIEP if compared to the EMEP inventory. For NMVOC, CIEP emissions are $43 \%$ higher for SNAP 2 and 31\% lower for SNAP 7 if compared to EMEP.

Table 1. Summary of SNAP sectors 2 and 7 emissions for Poland for EMEP and CIEP inventories (units: $\mathrm{Gg} ; \mathrm{NO}_{\mathrm{x}}=\mathrm{NO}+\mathrm{NO}_{2}$, as $\mathrm{NO}_{2}$ )

\begin{tabular}{lcccccccc}
\hline & \multicolumn{4}{c}{ EMEP } & \multicolumn{4}{c}{ CIEP } \\
\cline { 2 - 9 } & NO $_{\mathbf{x}}$ & $\mathbf{P M 1 0}$ & PM2.5 & NMVOC & NO $_{\mathbf{x}}$ & PM10 & PM2.5 & NMVOC \\
\cline { 2 - 9 } SNAP2 & 165.1 & 203.9 & 145.7 & 278.6 & 136.1 & 315.3 & 305.1 & 430.2 \\
SNAP7 & 455.9 & 32.3 & 24.4 & 192.0 & 810.3 & 67.5 & 58.0 & 141.0 \\
\hline
\end{tabular}

Application of two inventories, significantly different in spatial resolution and total mass of emitted pollutants will address two issues: 
1. What is the impact of the emission inventory on modelled PM2.5, PM10 and $\mathrm{O}_{3}$ exposure-related indices?

2. What is the impact of SNAP sectors 2 (residential combustion) and 7 (road traffic) on PM2.5, $\mathrm{PM} 10$ and $\mathrm{O}_{3}$ exposure-related indices?

For both emission scenarios (EMEP and CIEP), the emission was re-gridded to $12 \times 12 \mathrm{~km}$ for the outer domain and $4 \mathrm{~km} \times 4 \mathrm{~km}$ for the inner domain, using dedicated script developed in $\mathrm{R}$ statistical software [35]. The scripts assured that the emission mass is conserved after regriding. The emission was distributed into 7 vertical layers according to the SNAP sectors as suggested in [36]. Biogenic emission was calculated with the MEGAN model [37]. Emissions from fire were taken from FINN Fire emission inventory [38].

\subsection{Model Evaluation}

Modelled concentrations of PM10, PM2.5 and $\mathrm{O}_{3}$ were compared with observational data provided by the Chief Inspectorate for Environmental Protection (https:/powietrze.gios.gov.pl/pjp/archives). The number of sites available for each year by station type and pollutant is given in Table 1. Two data sets were available here for model-measurements comparison for PM2.5 and PM10: hourly and 24-h mean concentrations. For $\mathrm{O}_{3}$, only hourly concentrations were available. Suburban and rural sites were merged into one group named "non-urban", as their total number is low compared to urban sites. The model performance is investigated for these two groups separately, as previous papers show that the model performance might differ between urban and non-urban sites [24].

Table 2. Number of measuring sites available for model evaluation for each year, grouped by station type and pollutant (number of stations with $1 \mathrm{~h} / 24-\mathrm{h}$ mean measurements)

\begin{tabular}{ccccccc}
\hline & \multicolumn{3}{c}{$\mathbf{2 0 1 7}$} & & \multicolumn{3}{c}{$\mathbf{2 0 1 8}$} \\
\cline { 2 - 7 } & $\mathrm{PM} 2.5$ & $\mathrm{PM} 10$ & $\mathrm{O}_{3}$ & $\mathrm{PM} 2.5$ & $\mathrm{PM} 10$ & $\mathrm{O}_{3}$ \\
urban & $40 / 85$ & $111 / 198$ & 67 & $45 / 89$ & $115 / 198$ & 71 \\
suburban & $5 / 9$ & $9 / 22$ & 14 & $5 / 8$ & $8 / 21$ & 12 \\
rural & $1 / 4$ & $3 / 10$ & 22 & $1 / 4$ & $3 / 14$ & 22 \\
\hline
\end{tabular}

To complement the model evaluation, we have also compared EMEP and CIEP WRF-Chem runs with measured secondary inorganic aerosols (SIA) mean concentrations for the study period. The measurements are gathered at five background stations operated within the European EMEP program and four CIEP stations. We have plotted modelled and measured mean concentrations of $\mathrm{SO}_{4}{ }^{2-}, \mathrm{NH}_{4}{ }^{+}$and $\mathrm{NO}_{3}{ }^{-}$. For stations with 24-h mean concentrations of SIA (EMEP network), we have also calculated model errors.

We used Normalized Mean Bias (NMB, eq. 1) and Index of Agreement (IOA, eq. 2) to summarize the model errors ( $\mathrm{O}$ is for observations, $\mathrm{M}$ for models and $\mathrm{N}$ for number of pairs model-observations). More information on these statistics is provided by [39] and [40]. The statistics were calculated according to months as a mean from all stations for the period of 2017-2018 and according to type of stations.

$$
\begin{gathered}
N M B=\frac{\sum_{i=1}^{N}\left(M_{i}-O_{i}\right)}{\sum_{i=1}^{N} O_{i}} * 100 \\
I O A=\frac{\sum_{i=1}^{N}\left(O_{i}-M_{i}\right)^{2}}{\sum_{i=1}^{N}\left(\left|M_{i}-\bar{O}\right|+\left|O_{i}-\bar{O}\right|\right)^{2}}
\end{gathered}
$$

where $O$ represents observations and $M$ represents measurements.

$\mathrm{NMB}$ and IOA error statistics were calculated for hourly concentrations of PM2.5, PM10 and $\mathrm{O}_{3}$ and for exposure-related indices [2], including the following:

- $\quad$ Twenty-four-hour mean concentrations of PM2.5 and PM10; 
- Twenty-four-hour maximum value of 8-h rolling mean $\mathrm{O}_{3}$ concentrations.

Finally, number of exceedances of critical levels, defined by WHO, for daily mean PM2.5 and PM10 concentrations and daily maximum 8-hour rolling mean $\mathrm{O}_{3}$ concentrations were calculated using modeled and observed data and compared. The threshold values according to the WHO air quality guidelines are as follows:

- Value of $25 \mathrm{\mu g} \mathrm{m}^{-3}$ for PM2.5 24-h mean;

- Value of $50 \mathrm{\mu g} \mathrm{m}^{-3}$ for PM10 24-h mean;

- Value of $100 \mu \mathrm{g} \mathrm{m}^{-3}$ for $\mathrm{O}_{3}$ 8-h rolling mean.

Error statistics and 8-h rolling mean values of $\mathrm{O}_{3}$ concentrations were calculated using $\mathrm{R}$ statistical software and Openair and tidyverse packages [35].

\section{Results}

Hourly measurements of PM2.5 and $\mathrm{O}_{3}$ concentrations for both years 2017 and 2018 are summarized in Figure 1. The same seasonal pattern was observed in 2017 and 2018. PM2.5 (and PM10 — not presented here) concentrations are the highest during the heating season, which lasts from October to March in Poland. During these months, concentrations of atmospheric aerosols are very high, and this is related to increased emission of primary particles from residential combustion. For PM2.5 and PM10 the variability of observed values is also higher during the heating season. During the warm half of the year, the variability of aerosols concentrations is significantly lower. Median values of $\mathrm{O}_{3}$ concentrations are the highest in spring, but the absolute maxima are observed in summer (Figure 1).
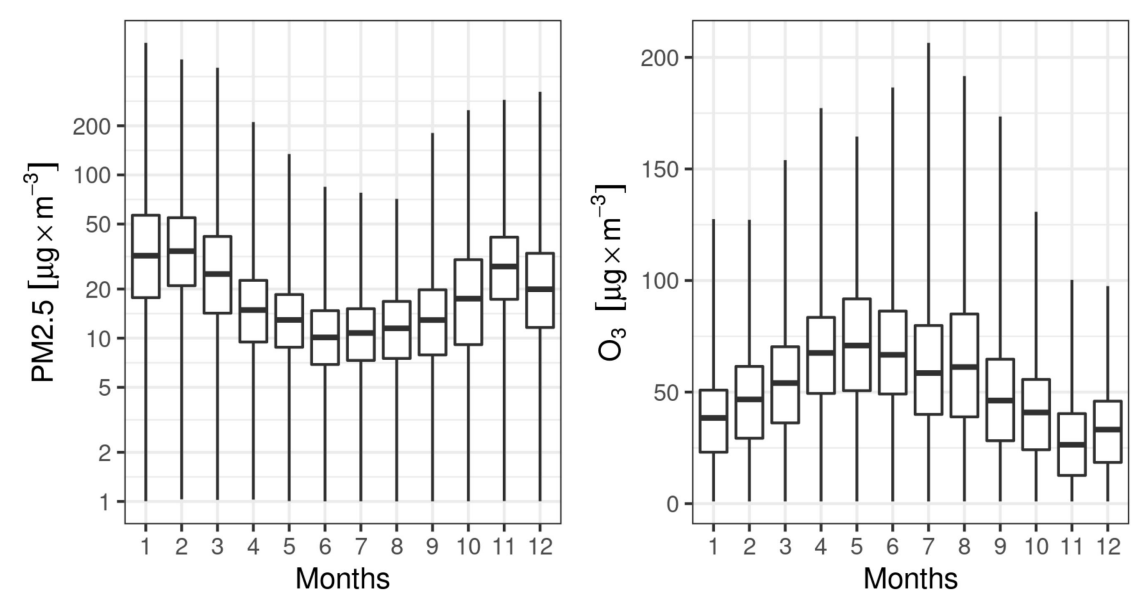

Figure 1. Hourly concentrations of PM2.5 and $\mathrm{O}_{3}$ observed in years 2017-2018 in Poland (please notice $\log$ y axis for PM2.5). Boxplot for each month summarizes all available measurements. Boxplots show: median, $25^{\text {th }}$ and $75^{\text {th }}$ percentile, minimum and maximum values.

Model performance for CIEP and EMEP runs has been summarized using the hourly measurements of PM2.5, PM10 and $\mathrm{O}_{3}$ in Figures 2-4. Both model runs show a similar annual pattern for NMB. PM2.5 and PM10 are underestimated in winter months. The negative bias is larger for the EMEP emission run and exceeds $60 \%$ both for PM2.5 and PM10. For summer months, the bias is significantly smaller, but still larger for the EMEP run.

For $\mathrm{O}_{3}$ both CIEP and EMEP are above the observed values for January-February and September-December. NMB is close to zero for March and August. For the remaining months, $\mathrm{O}_{3}$ is underestimated. Both model runs show similar seasonal pattern for NMB.

For PM2.5 and PM10, change in emission from EMEP to CIEP increases the IOA values. For PM2.5, this increase is larger during the summer months (Figure 2). For PM10 (Figure 3), there is no distinct 
annual pattern in IOA. For both model runs the smallest IOA for PM10 are for winter. For ozone, the change in emission inventory does not influence the IOA values significantly (Figure 4). The highest IOA values for ozone are observed in June and July. For October-December, IOA drops for CIEP and keeps the same value (close to 0.6) for the EMEP run.

a

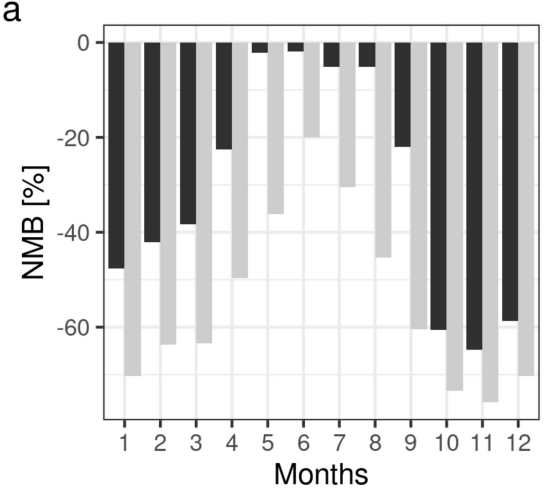

b

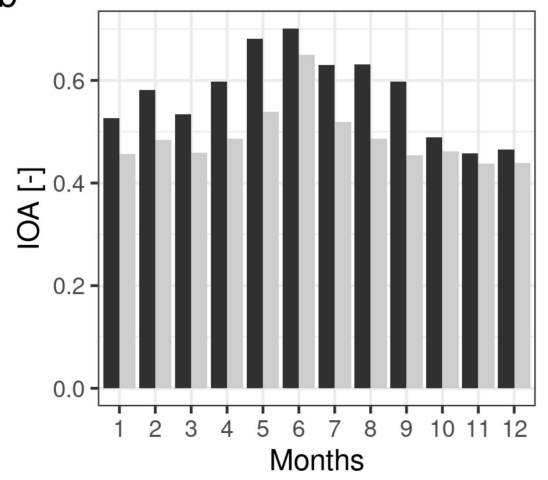

CIEP

EMEP

Figure 2. Normalized mean bias (a) and Index of Agreement (b) for hourly PM2.5 concentrations, calculated for each month (years 2017-2018) from all available stations

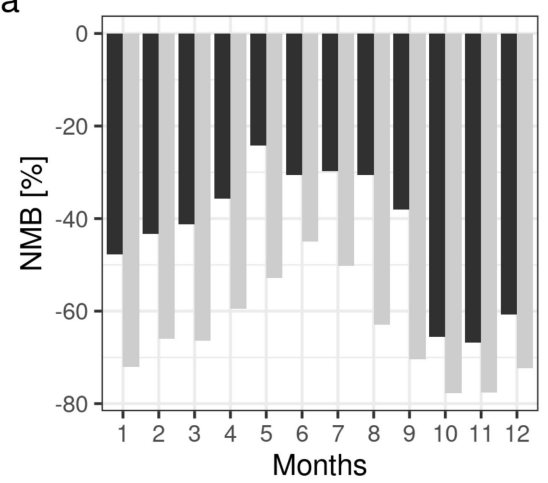

b

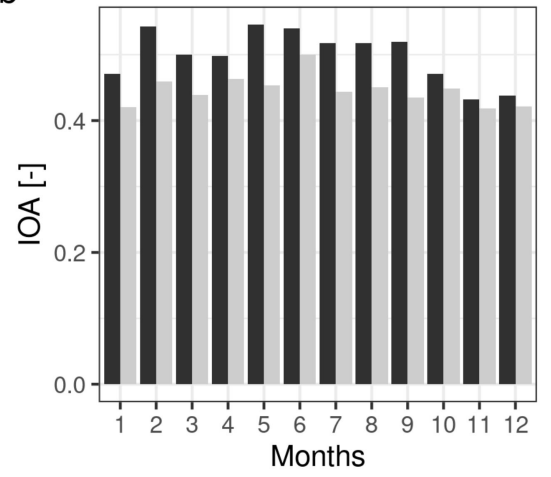

$\square$ CIEP

EMEP

Figure 3. Normalized mean bias (a) and Index of Agreement (b) for hourly PM10 concentrations, calculated for each month (years 2017-2018) from all available stations

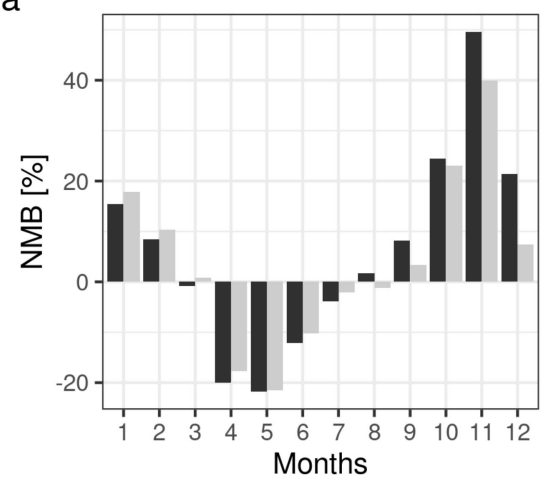

b

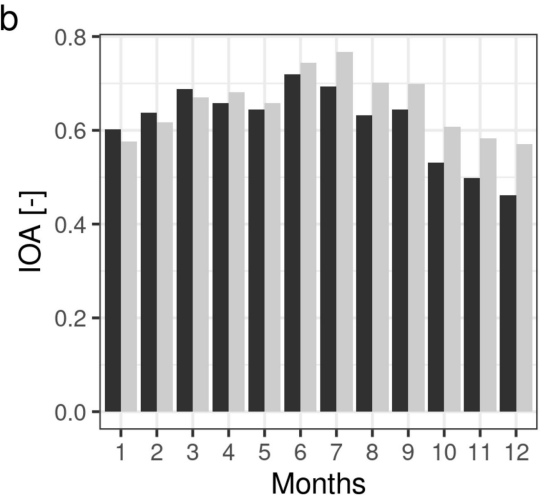

CIEP

EMEP

Figure 4. Normalized mean bias (a) and Index of Agreement (b) for hourly $\mathrm{O}_{3}$ concentrations calculated for each month (years 2017-2018) from all available stations 
The WRF-Chem model performance for SIA is very similar for CIEP and EMEP (Figure 5). On average, the model represents well $\mathrm{SO}_{4}{ }^{2-}$ and $\mathrm{NH}_{4}{ }^{+}$and significantly underestimates $\mathrm{NO}_{3}{ }^{-}$. For $\mathrm{SO}_{4}{ }^{2-}$ both simulations overestimate observed concentrations in winter (up to $40 \%$ in February) and underestimate them from March to November. Index of agreement is also similar for EMEP and CIEP, and is the highest (c.a. 0.6) for winter months. For the remaining months, IOA is close to 0.5 for both model runs. For $\mathrm{NH}_{4}{ }^{+}$, EMEP and CIEP show similar patterns, with maximum IOA in winter exceeding 0.7. $\mathrm{NH}_{4}{ }^{+}$concentrations are underestimated for all months except December. $\mathrm{NO}_{3}{ }^{-}$is underestimated for all months both for EMEP and CIEP.
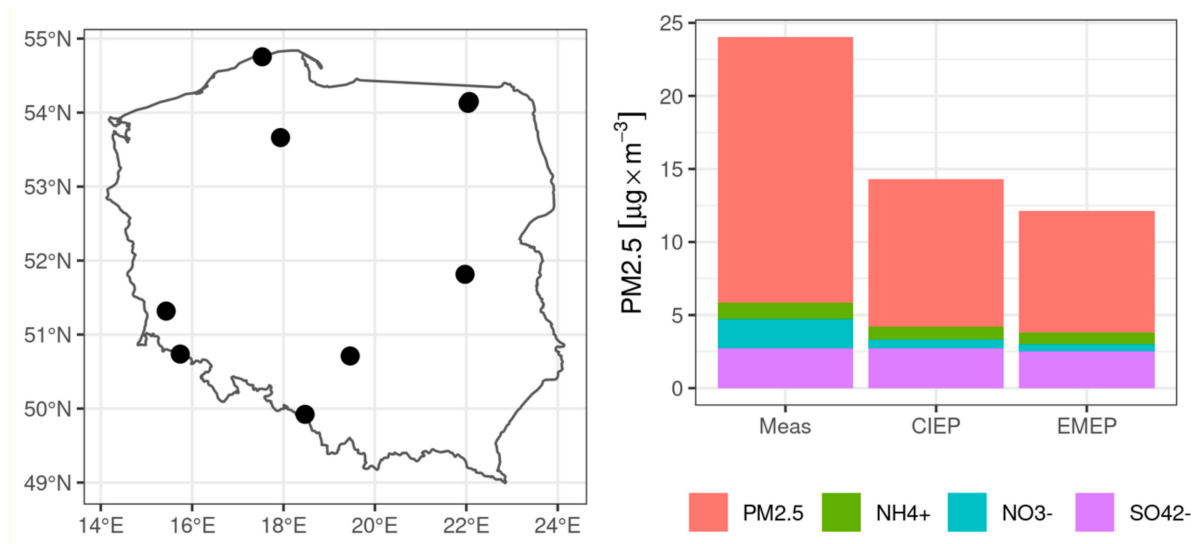

Figure 5. Location of the secondary inorganic aerosols (SIA) measuring sites and SIA concentrations in total PM2.5 (mean values for all stations and study period).

Instead of hourly measurements, the health effects are often analyzed in terms of daily mean values of PM2.5/PM10 or daily maximum of 8-hour rolling mean concentration of $\mathrm{O}_{3}$. The number of stations that provide 24-h mean measurements for PM2.5 and PM10 is larger if compared to hourly data (Table 2). The annual pattern of NMB for 24-h mean of aerosols is similar to the one calculated for hourly data (Figure 6). Both simulations underestimate the observed 24-h mean concentrations of particulate matter. This underestimation is the largest for winter months and the EMEP run. Simulation with modified emission for residential combustion and transport has smaller bias, but both PM2.5 and PM10 daily mean concentrations are still underestimated.

For the EMEP run, there is a significant difference in the model performance between the stations' type. NMB for urban stations is higher if compared to non-urban stations, especially in winter. For CIEP and non-urban stations 24-h mean PM2.5 and PM10 are also better reproduced in terms of NMB, and the difference between urban and non-urban stations is smaller if compared to the EMEP run. IOA values for PM2.5 and PM10 are at similar level regardless of the season and are higher for CIEP if compared to EMEP (Figures 6 and 7). IOA values are also similar for urban and non-urban sites.

For daily maximum of 8 -h rolling mean concentrations of ozone, there is a similar annual pattern in the model performance to the one observed for hourly data (Figure 8). During winter, both model runs have positive NMBs, with larger values for urban stations. From spring to fall, the model underestimates $24 \mathrm{~h}$ maximum of 8-h rolling mean values, and this underestimation is larger for non-urban sites. Both ME and IOA values are similar for the EMEP and CIEP runs. For IOA, there is no significant seasonal pattern.

The days with values exceeding the threshold for PM2.5 and PM10 are observed in the cold season. The CIEP model run reproduces well the number of days with the PM2.5 daily mean above the $25 \mu \mathrm{g} \mathrm{m}^{-3}$ WHO guideline limit (Table 3). For EMEP, the number of days with daily concentration exceeding this threshold is significantly lower. Both simulations underestimate the total number of days with 24-h mean PM10 concentrations exceeding $50 \mu \mathrm{g} \mathrm{m}^{-3}$. The same is true for ozone, for which number of days with daily maximum of 8-hour mean concentrations exceeding $100 \mu \mathrm{g} \mathrm{m}^{-3}$ is 
underestimated both for CIEP and EMEP. For ozone, days with threshold values exceeded are observed in the warm half of the year.
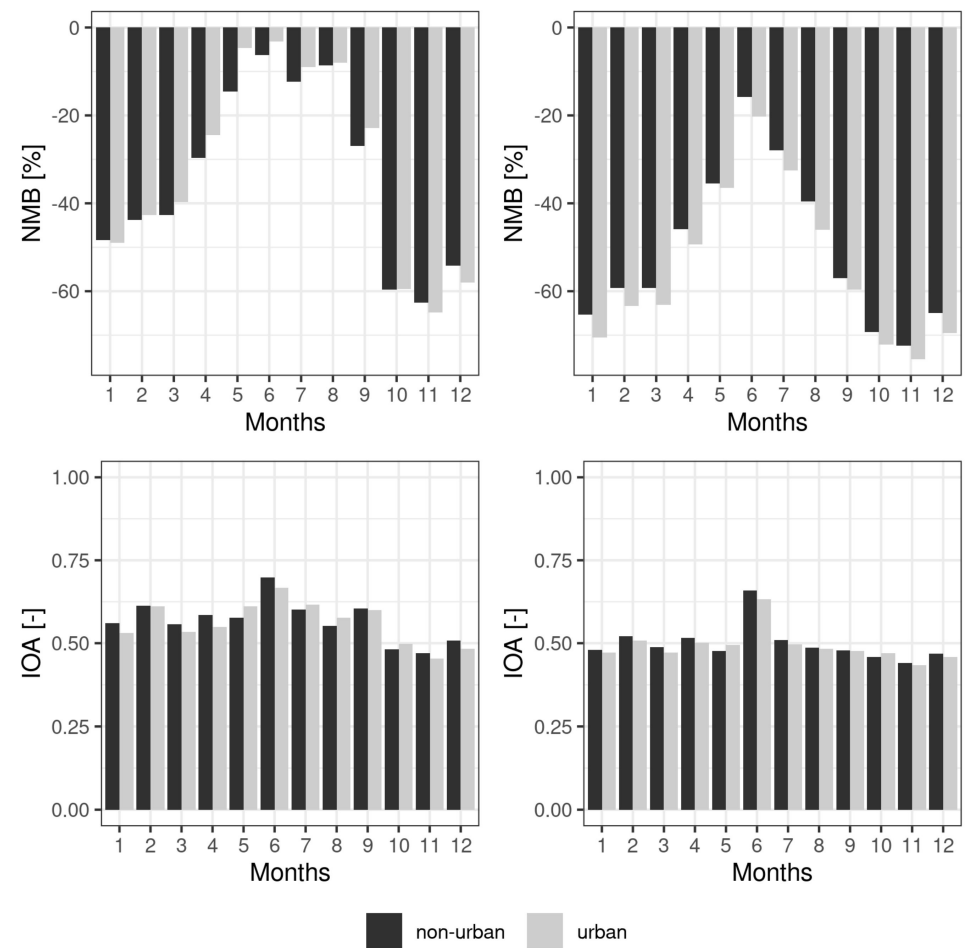

Figure 6. Normalized mean bias and index of agreement for 24-h mean PM2.5 concentrations for CIEP (left) and EMEP (right) emission runs calculated for each month and station type (years 2017-2018).
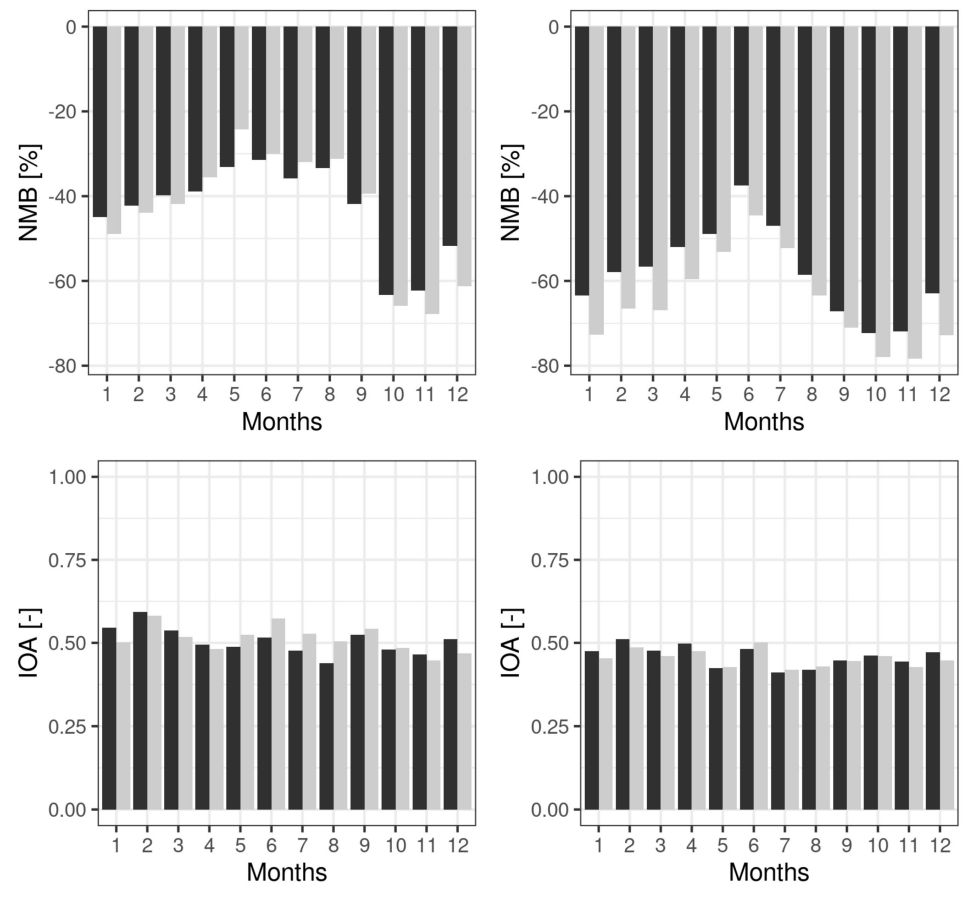

non-urban urban

Figure 7. Normalized mean bias and index of agreement for 24-h mean PM10 concentrations for CIEP (left) and EMEP (right) emission runs calculated for each month and station type (years 2017-2018). 

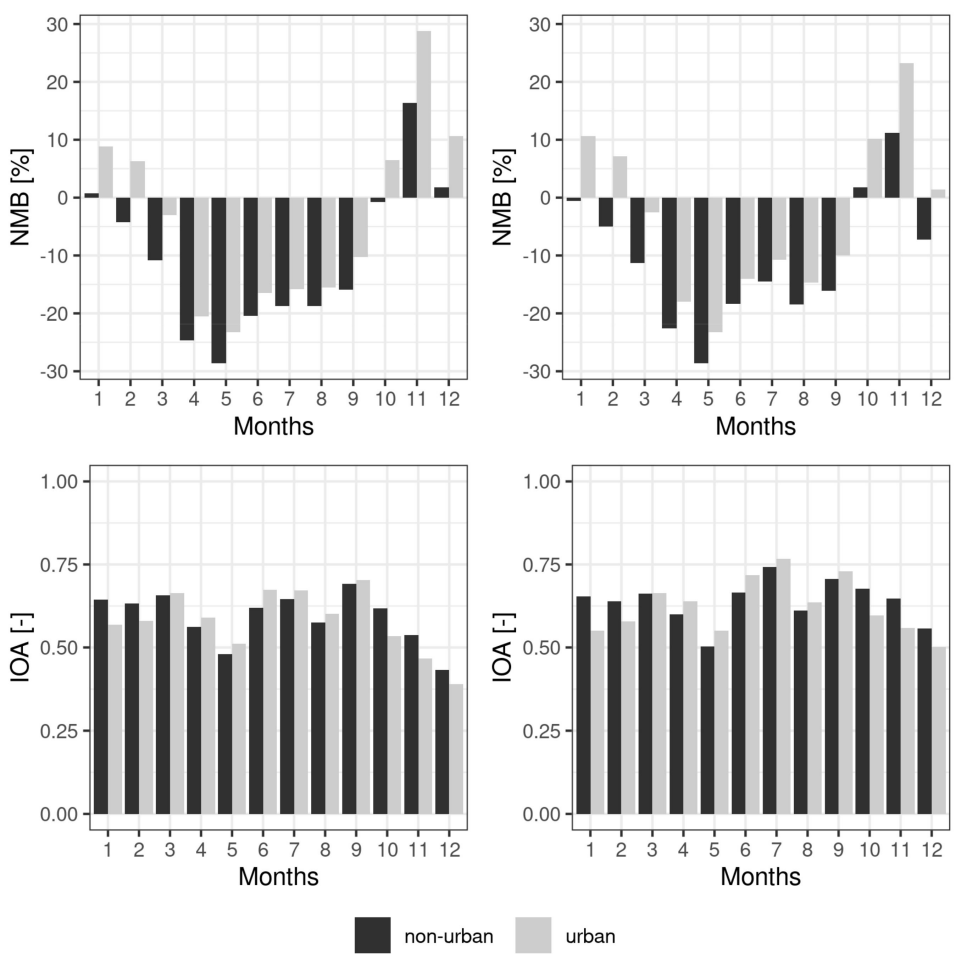

Figure 8. Mean error and index of agreement for 24-h maximum of 8-hour rolling mean of $\mathrm{O}_{3}$ concentrations for CIEP (left) and EMEP (right) emission runs calculated for each month and station type (years 2017-2018).

Table 3. Number of days (for all stations) with threshold values exceeded for 24-h mean PM2.5, PM10 and 24-h maximum 8-h rolling mean for $\mathrm{O}_{3}$.

\begin{tabular}{cccc}
\hline & CIEP & EMEP & Observed \\
\hline PM2.5 & 19515 & 5220 & 19799 \\
PM10 & 3652 & 300 & 22985 \\
$\mathrm{O}_{3}$ & 4716 & 6014 & 10970 \\
\hline
\end{tabular}

The spatial pattern of PM2.5 is presented using February 2018 mean values as an example (the highest PM2.5 and PM10 were observed in February) in Figure 9. Concentrations calculated with CIEP run are significantly higher than EMEP. In addition, CIEP emission data are capable of reproducing small towns, with relatively high emission of primary particulates. These locations are missing if the EMEP emission inventory is used, as more local emission is averaged out in a large grid cell. However, the general spatial pattern in monthly concentration is similar. The highest concentrations are calculated over the southern areas of the country, including Upper Silesia and Kraków. Grid-to-grid correlation is close to 0.90 and the mean difference is close to $3.1 \mu \mathrm{g} \mathrm{m}^{-3}$. A similar spatial pattern in monthly concentration and agreement between the CIEP and EMEP run is observed for PM10. 


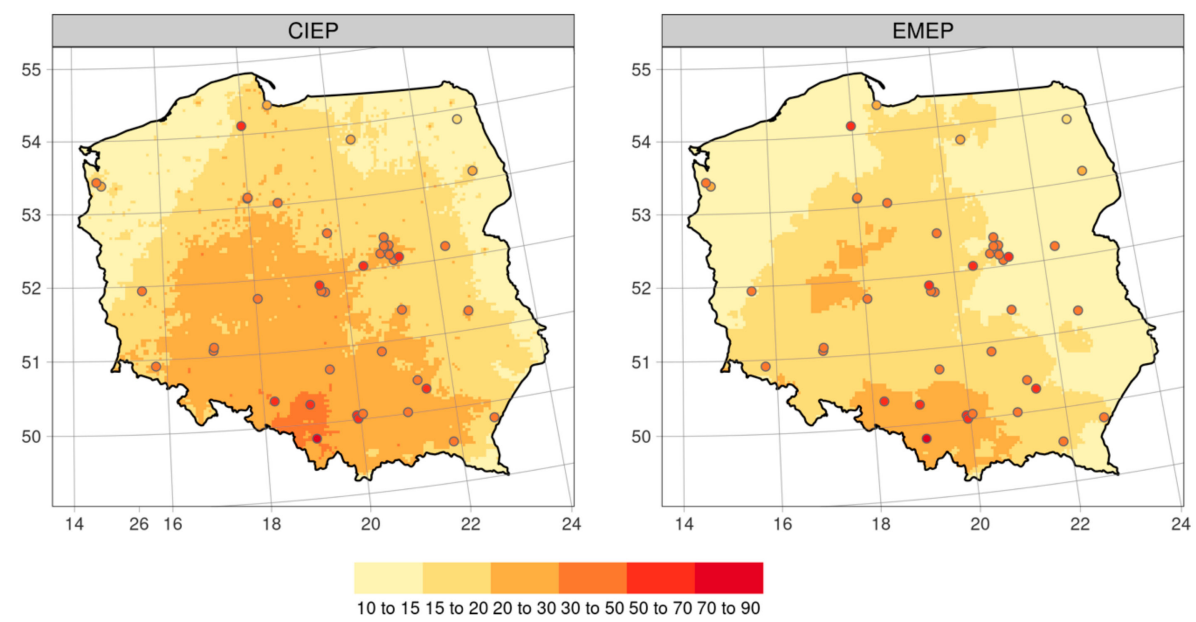

Figure 9. February 2018 monthly mean PM2.5 concentrations for CIEP and EMEP. Dots show PM2.5 concentrations measured at stations (units are $\mu \mathrm{g} \mathrm{m}^{-3}$ ).

February 2018 hourly PM2.5 concentrations are also presented in detail for Katowice station (18.97E, 50.27N; Figure 10). The station is located in the center of the highly polluted area of Upper Silesia. The station is strongly affected by the emission from residential coal combustion. The model-measurement agreement is significantly improved for the CIEP run. Still, the peaks are underestimated, but this shows the role of the residential combustion for PM2.5 concentrations. Similar patterns are observed for PM10 and other stations affected by residential heating emissions in Poland.

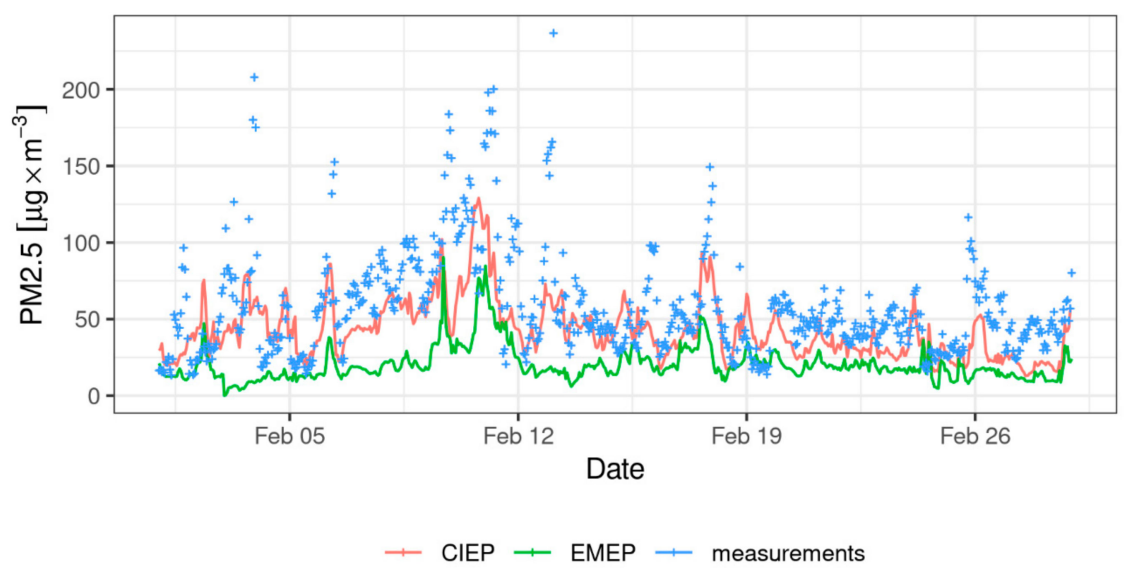

Figure 10. PM2.5 hourly concentrations for Katowice station (S Poland) for February 2018.

Monthly mean concentrations of $\mathrm{O}_{3}$ are presented for May 2018 (Figure 11). For this month, the highest concentrations of $\mathrm{O}_{3}$ were measured during the study period. Spatial patterns are similar for both CIEP and EMEP runs. Grid-to-grid correlation is 0.99 , and mean difference is $2.9 \mu \mathrm{g} \mathrm{m}^{-3}$. Both simulations show the highest $\mathrm{O}_{3}$ concentrations over the west and south (mountains) of Poland, with decreasing spatial trend towards the coldest $\mathrm{NE}$ areas. EMEP run gives higher $\mathrm{O}_{3}$ concentrations than CIEP. 


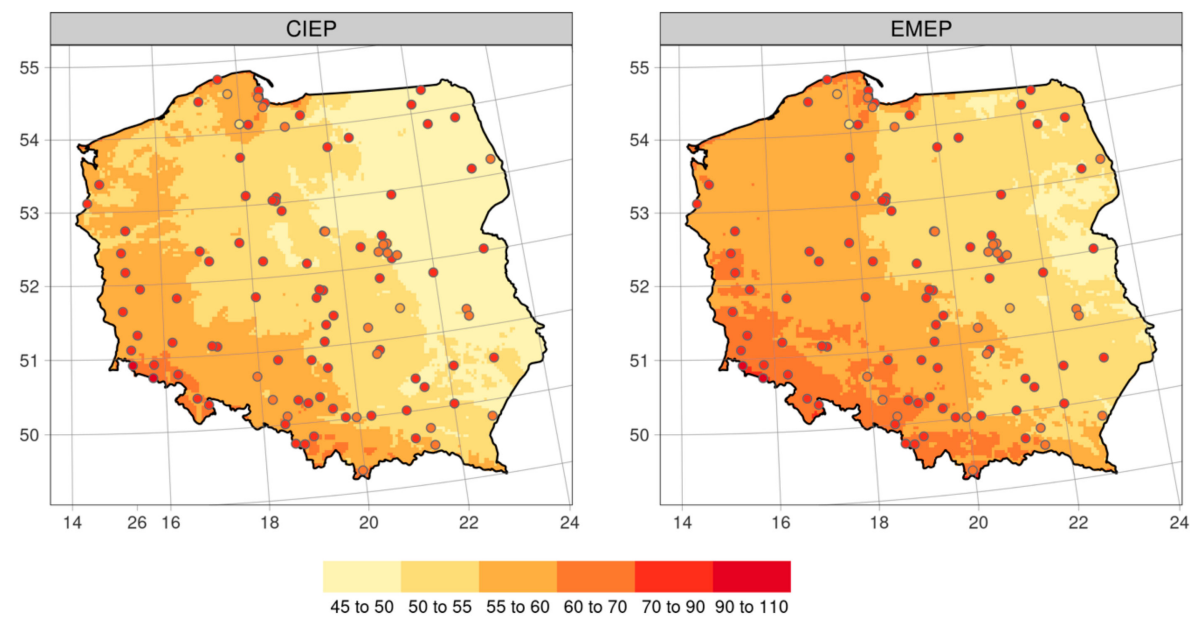

Figure 11. May 2018 monthly mean $\mathrm{O}_{3}$ concentrations for CIEP and EMEP. Symbols show $\mathrm{O}_{3}$ concentrations measured at stations (units are $\mu \mathrm{g} \mathrm{m}^{-3}$ ).

\section{Discussion}

In this work we have compared the WRF-Chem model simulations for years 2017 and 2018 for PM2.5, PM10 and $\mathrm{O}_{3}$ with measurements and health-related metrices recommended by WHO. The model has been run twice for each year, using two different emission inventories. The source resolution of the EMEP emission inventory is available at $0.1^{\circ} \times 0.1^{\circ}$ grid (approx. $8 \mathrm{~km} \times 8 \mathrm{~km}$ ). This inventory was regridded into the $4 \mathrm{~km} \times 4 \mathrm{~km}$ WRF-Chem model mesh. The coarser source resolution of the EMEP emission inventory means that the local hot spots of PM2.5 and PM10 emissions are averaged out over the coarse grid mesh. In contrast, source resolution of the CIEP emission inventory is $1 \mathrm{~km} \times 1 \mathrm{~km}$. The local emission hot spots, especially small towns where emission from individual heating sources is large, are better reproduced also after aggregation into the $4 \mathrm{~km} \times 4 \mathrm{~km}$ WRF-Chem model mesh (Figure 12). The same is true for e.g., emission from road transport-for CIEP emission, after aggregation to $4 \mathrm{~km} \times 4 \mathrm{~km}$ grid, the number of details is higher (Figure 13).

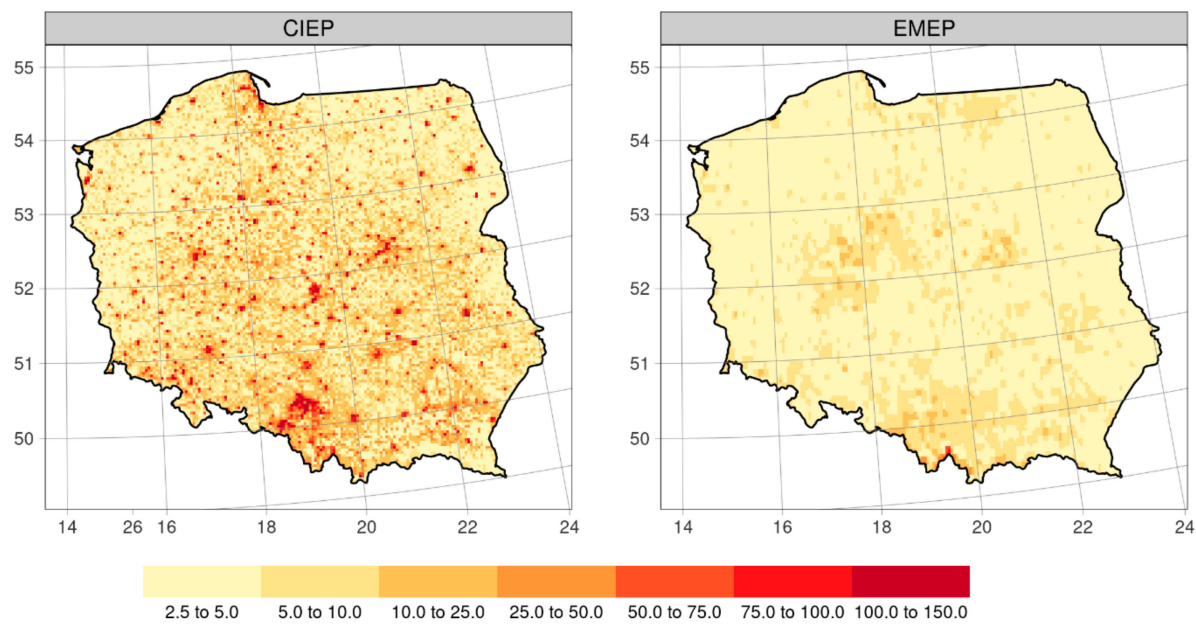

Figure 12. Annual PM2.5 emission from residential combustion $\left(\mathrm{kg} \mathrm{grid}^{-1}\right)$. 


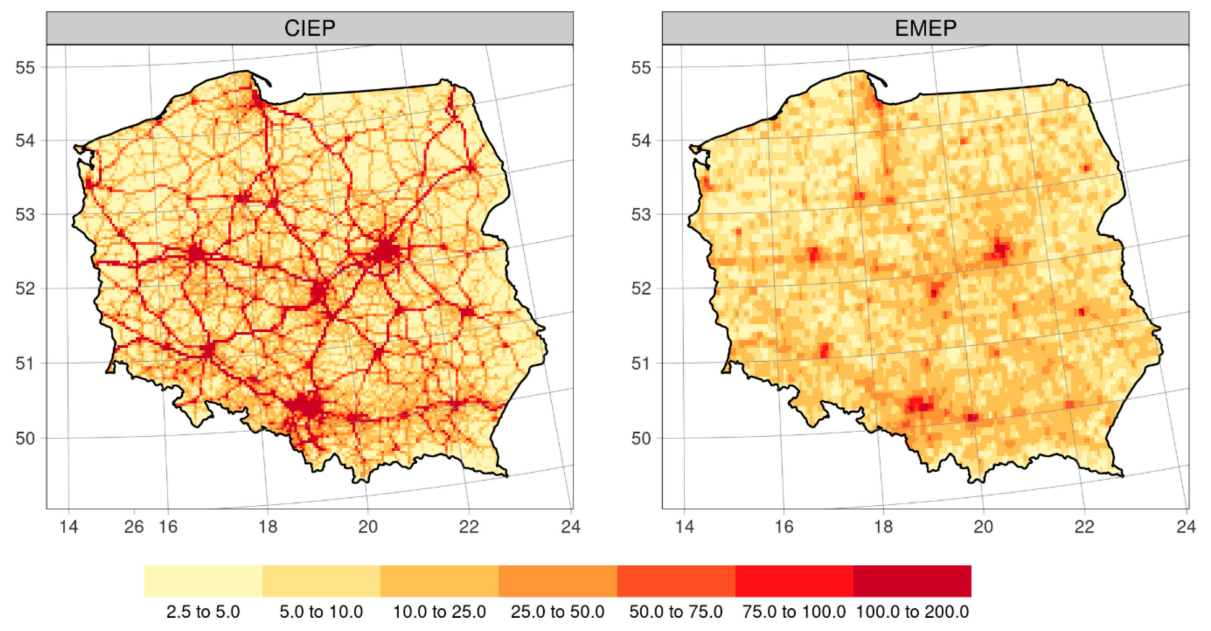

Figure 13. Annual $\mathrm{NO}_{\mathrm{x}}$ emission from road transport $\left(\mathrm{kg} \mathrm{grid}^{-1}\right)$.

Apart from the differences introduced by the various source resolutions of the emission inventories, there are large discrepancies in total mass of emitted pollutants from residential combustion and road transport. Primary particulate matter (PM) emissions are significantly higher for CIEP than EMEP. This might be related to the differences in input activity data and emission factors. This has a large impact on the WRF-Chem model performance for PM2.5 and PM10. Concentrations of these pollutants are significantly underestimated, especially for the heating seasons. Similar findings were earlier reported by other researchers, e.g., $[24,25,33]$. This bias is reduced when emission from residential combustion is increased, e.g., by replacing EMEP emission with CIEP national emission inventory. This change not only reduces NMB, but also increases IOA.

The change of emission inventory has significant impact on modelled PM2.5 and PM10 concentrations, but it does not improve the model performance for secondary pollutants i.e., ozone or SIA. The WRF-Chem model performance for $\mathrm{O}_{3}$ was found to be very similar for both CIEP and EMEP runs, despite the significant changes in emission totals (e.g., from road transport) and their spatial allocations. This suggests that there are other significant processes responsible for ozone formation, e.g., model chemistry, VOCs emission or meteorology and the impact of $\mathrm{NO}_{\mathrm{x}}$ emission on the model performance is limited. Additionally, the spatial scale of ozone episodes is larger than that of PM episodes.

The WRF-Chem model gives higher $\mathrm{O}_{3}$ concentrations for the EMEP run compared to the CIEP run. Simultaneously, $\mathrm{CIEP}$ inventory gives more $\mathrm{NO}_{x}$ and $\mathrm{NMVOC}$ emissions (potential $\mathrm{O}_{3}$ precursors) compared to the EMEP database. It basically means that higher emission of precursors results in lower $\mathrm{O}_{3}$ concentrations in Poland. Previous study with WRF-Chem in Poland for June-August 2015 showed that for the majority of Poland, ozone production regime shows mixed sensitivity to emissions of precursors, but with slightly better response (in decrease of $\mathrm{O}_{3}$ ) to $\mathrm{NO}_{\mathrm{x}}$ reduction [20]. The results showed that anthropogenic emission has large influence on ozone concentrations and both $\mathrm{NO}_{\mathrm{x}}$ and NMVOC emission control would be beneficial for air quality and would lower the risk and frequency of high ozone episodes during summer, in particular in central and southern parts of the country. However, the situation might be different for other seasons or periods [41]. In general, $\mathrm{O}_{3}$ concentrations can increase due to decrease of $\mathrm{NO}_{\mathrm{x}}$ and NMVOC emissions in NMVOC and $\mathrm{NO}_{\mathrm{x}}$ sensitive regime, respectively [42].

There are also significant seasonal changes in WRF-Chem model performance for ozone. $\mathrm{O}_{3}$ is underestimated for spring and summer months and overestimated for fall and winter. Overestimation of $\mathrm{O}_{3}$ with CMAQ model was reported earlier by [23]. For spring, and, to a lesser extent summer, the CMAQ model was underestimating observed $\mathrm{O}_{3}$, similar to the WRF-Chem performance presented here. There are differences for winter, where [23] reports underestimations of observed $\mathrm{O}_{3}$ concentrations. 
Application of the CIEP emission inventory considerably increased the number of days that PM2.5 exceeded the WHO recommended threshold value for 24-h mean concentrations of PM2.5. There was also large improvement for the number of days that PM10 exceeded the 24-hour threshold 24-h mean (from c.a. 300 to over 3600 cases), but the gap between the observed and modelled number of days with exceedances is large for PM10 (number of observed cases is close to 23,000). This suggests two issues:

- Residential combustion and transport are important sources of PM2.5 and PM10 and significantly contribute to the number of days with WHO threshold values exceeded. Significant effort should be made to reduce emission from these two sectors, as well as to improve the emission inventories for these two sectors. This is in agreement with recent measurement-based studies [43], where the authors show, using the positive matrix factorization approach, that the residential combustion and traffic exhaust are the most prevalent contributing sources to PM2.5 concentrations.

- Coarse PM emissions might be still too low. There might be some other, missing sources not included or underestimated in the emission inventories. The authors in $[24,25]$ suggest that it could be related to, e.g., missing dust emission. This could be also linked to, e.g., underestimated non-exhaust emission $[43,44]$.

The high-resolution emission inventory used in this study helps to better distinguish the polluted urban and suburban areas from rural ones. This was earlier suggested by [45]. The model performance for urban and non-urban areas is similar if a high-resolution emission inventory is used for PM2.5 and PM10, but if the coarse resolution inventory is used, the differences are larger. Again, the change in emission inventory has only limited impact on model performance in terms of $\mathrm{O}_{3}$.

The WRF-Chem model configuration used here uses new RACM-VBS chemical and aerosols treatment mechanisms. This scheme was tested in detail for the United States and showed significant improvements in model performance for, e.g., secondary organic aerosols. Earlier studies with different treatment of aerosols, especially with the GOCART scheme, show lower agreement between the model and measurements in summer. Application of the RACM-VBS scheme significantly improved the model performance this season. This also shows that for summer, secondary organic aerosols have a significant contribution to total PM2.5 and PM10.

\section{Conclusions}

In this paper we have summarized the WRF-Chem model runs for two years for Poland, Central Europe. Because of very characteristic, coal-dominated fuel usage, Poland is a specific country in terms of emission. We have compared the model performance for various sets of observations, including hourly, daily and 8-h running average values of PM2.5, PM10 and $\mathrm{O}_{3}$. The main conclusions of this work are listed below:

- Application of national emission inventory, with high spatial resolution and significantly higher total emission of primary aerosols, significantly improves the model performance in terms of bias, IOA and number of days with WHO threshold values exceeded.

- Application of national emission inventory does not improve the model performance for secondary pollutants like tropospheric ozone. Number of days with exceedance of the WHO limit value is underestimated for both model runs.

- Number of days which exceeded PM10 24-h mean value threshold of $50 \mathrm{\mu g} \mathrm{m}^{-3}$ calculated with the WRF-Chem model is underestimated both for EMEP and, to less extent, CIEP inventories. This suggest some missing mass of emitted coarse particles or missing emission sources.

- Application of the RACM-VBS chemical and aerosols mechanisms improved the WRF-Chem model performance for summer, if compared to the previously published results.

The effect of emission inventory source resolution should be further investigated, e.g., by running the model at coarser resolution and CIEP emission inventory aggregated into, e.g., $12 \mathrm{~km} \times 12 \mathrm{~km}$ grid. 
The effect of the emission inventory on assessment of economic costs of air pollution on human health should be further investigated.

Author Contributions: M.K.: research idea, preparing the input data for the WRF-Chem model, running the WRF-Chem model, evaluation of the model results, preparing measurements for model evaluation, writing the manuscript. M.W.: writing the manuscript. J.D.: writing the manuscript, preparing the plots for the manuscript. A.J.D.: writing the manuscript. All authors have read and agreed to the published version of the manuscript.

Funding: This work was supported by the Polish National Science Centre grant no UMO-2017/25/B/ST10/01041. The research was supported by the European Union's Horizon 2020 research and innovation program under grant agreement No 856599

Acknowledgments: Emissions data for Poland $(1 \mathrm{~km} \times 1 \mathrm{~km}$ and $500 \mathrm{~m} \times 500 \mathrm{~m}$ for cities) and air quality measurements were provided by the Chief Inspectorate of Environmental Protection (http://www.gios.gov.pl/en/, direct contact to the institution). Emission data were prepared for the year 2016 within the project: "Supporting the air quality assessment system with application of modelling of PM10, PM2.5, SO2, NO2, B(a)P for the years 2015, 2016 and 2017". WRF-Chem modelling was carried out on the computers of the Wroclaw Centre for Networking and Supercomputing (http://www.wcss.wroc.pl), Grant No. 170.

Conflicts of Interest: The authors declare no conflict of interest.

\section{References}

1. WHO. Review of evidence on health aspects of air pollution - REVIHAAP Project; Europe. 2013. Available online: https://www.euro.who.int/_data/assets/pdf_file/0004/193108/REVIHAAP-Final-technical-report.pdf (accessed on 3 July 2020).

2. WHO Regional Office for Europe. Health risks of air pollution in Europe - HRAPIE project; Denmark. 2013. Available online: https://www.euro.who.int/_data/assets/pdf_file/0006/238956/Health_risks_air_pollution_ HRAPIE_project.pdf?ua $=238951$ (accessed on 3 July 2020).

3. Lapko, A.; Panasiuk, A.; Strulak-Wójcikiewicz, R.; Landowski, M. The state of air pollution as a factor determining the assessment of a city's tourist attractiveness-based on the opinions of polish respondents. Sustainability 2020, 12, 1466. [CrossRef]

4. Lelieveld, J.; Klingmüller, K.; Pozzer, A.; Pöschl, U.; Fnais, M.; Daiber, A.; Münzel, T. Cardiovascular disease burden from ambient air pollution in Europe reassessed using novel hazard ratio functions. Eur. Heart J. 2019, 40, 1590-1596. [CrossRef] [PubMed]

5. Rogula-Kozłowska, W.; Majewski, G.; Widziewicz, K.; Rogula-Kopiec, P.; Tytła, M.; Mathews, B.; Ciuka-Witrylak, M. Seasonal variations of PM1-bound water concentration in urban areas in Poland. Atmos. Pollut. Res. 2018, 10, 267-273. [CrossRef]

6. Lewandowska, A.U.; Falkowska, L.M. High concentration episodes of PM10 in the air over the urbanized coastal zone of the Baltic Sea (Gdynia - Poland). Atmos. Res. 2013, 120-121, 55-67. [CrossRef]

7. Górka, M.; Lewicka-Szczebak, D. One-year spatial and temporal monitoring of concentration and carbon isotopic composition of atmospheric $\mathrm{CO}_{2}$ in a Wroclaw (SW Poland) city area. Appl. Geochem. 2013, 35, 7-13. [CrossRef]

8. Reizer, M.; Juda-Rezler, K. Explaining the high PM10 concentrations observed in Polish urban areas. Air Quality. Atmosphere Healh. 2016, 9, 517-531. [CrossRef]

9. Bebkiewicz, K.; Chłopek, Z.; Doberska, A.; Kanafa, M.; Kargulewicz, I.; Olecka, A.; Rutkowski, J.; Skośkiewicz, J.; Waśniewska, S.; Zasina, D.; et al. Pjoland ' s Informative Inventory Report 2020; 2020; Warsaw, Poland. Available online: www.ciep.at (accessed on 3 July 2020).

10. Czernecki, B.; Półrolniczak, M.; Kolendowicz, L.; Marosz, M.; Kendzierski, S.; Pilguj, N. Influence of the atmospheric conditions on PM10 concentrations in Poznań, Poland. J. Atmos. Chem. 2017, 74, 115-139. [CrossRef]

11. Grewling, Ł.; Frątczak, A.; Kostecki, Ł.; Nowak, M.; Szymańska, A.; Bogawski, P. Biological and chemical air pollutants in an urban area of central europe: Co-exposure assessment. Aerosol Air Qual. Res. 2019, 19, 1526-1537. [CrossRef]

12. Rogula-Kozłowska, W.; Kozielska, B.; Klejnowski, K.; Szopa, S. Hazardous compounds in urban PM in the central part of upper Silesia (Poland) in winter. Arch. Environ. Prot. 2013, 39, 53-65. [CrossRef]

13. Sówka, I.; Kobus, D.; Skotak, K.; Zathey, M.; Merenda, B.; Paciorek, M. Assessment of the health risk related to air pollution in selected polish health resorts. J. Ecol. Eng. 2019, 20, 132-145. [CrossRef] 
14. Krynicka, J.; Drzeniecka-Osiadacz, A. Analysis of Variability in PM 10 Concentration in the Wrocław Agglomeration. Polish J. Environ. Stud. 2013, 22, 1091-1099.

15. World Bank. Air Quality Management - Poland; World Bank Group: Washington, DC, USA, 2019; Available online: http://documents.worldbank.org/curated/en/574171554178748054/Air-Quality-Management-inPoland (accessed on 3 July 2020).

16. EMEP/CEIP. Emissions as used in EMEP models. Available online: https://www.ceip.at/ms/ceip_home1/ ceip_home/webdab_emepdatabase/index.html (accessed on 3 July 2020).

17. Andersen, H.R.; Spix, C.; Medina, S.; Schouten, J.P.; Castellsague, J.; Rossi, G.; Zmirou, D.; Touloumi, G.; Wojtyniak, B.; Ponka, A.; et al. Air pollution and daily admissions for chronic obstructive pulmonary disease in 6 European cities: Results from the APHEA project. Eur. Respir. J. 1997, 10, 1064-1071. [CrossRef] [PubMed]

18. Filleul, L.; Cassadou, S.; Médina, S.; Fabres, P.; Lefranc, A.; Eilstein, D.; Le Tertre, A.; Pascal, L.; Chardon, B.; Blanchard, M.; et al. The relation between temperature, ozone, and mortality in nine French cities during the heat wave of 2003. Environ. Health Perspect. 2006, 114, 1344-1347. [CrossRef]

19. Porter, W.C.; Heald, C.L. The mechanisms and meteorological drivers of the summertime ozoneerature relationship. Atmos. Chem. Phys. 2019, 19, 13367-13381. [CrossRef]

20. Wałaszek, K.; Kryza, M.; Werner, M. The role of precursor emissions on ground level ozone concentration during summer season in Poland. J. Atmos. Chem. 2017, 75, 181-204. [CrossRef]

21. Pawlak, I.; Jarosławski, J. Forecasting of surface ozone concentration by using artificial neural networks in rural and urban areas in central Poland. Atmosphere 2019, 10. [CrossRef]

22. Struzewska, J.; Kaminski, J.W. Formation and transport of photooxidants over Europe during the July 2006 heat wave - Observations and GEM-AQ model simulations. Atmos. Chem. Phys. 2008, 8, 721-736. [CrossRef]

23. Appel, K.W.; Chemel, C.; Roselle, S.J.; Francis, X.V.; Hu, R.-M.; Sokhi, R.S.; Rao, S.T.; Galmarini, S. Examination of the Community Multiscale Air Quality (CMAQ) model performance over the North American and European domains. Atmos. Environ. 2012, 53, 142-155. [CrossRef]

24. Im, U.; Bianconi, R.; Solazzo, E.; Kioutsioukis, I.; Badia, A.; Balzarini, A.; Baró, R.; Bellasio, R.; Brunner, D.; Chemel, C.; et al. Evaluation of operational online-coupled regional air quality models over Europe and North America in the context of AQMEII phase 2. Part II: Particulate matter. Atmos. Environ. 2015, 115, 421-441. [CrossRef]

25. Im, U.; Brandt, J.; Geels, C.; Hansen, K.M.; Christensen, J.H.; Andersen, M.S. Assessment and economic valuation of air pollution impacts on human health over Europe and the United States as calculated by a multi-model ensemble in the framework of AQMEII3. Atmos. Chem. Phys. 2018, 18, 5967-5989. [CrossRef]

26. Grell, G.A.; Peckham, S.E.; Schmitz, R.; McKeen, S.A.; Frost, G.; Skamarock, W.C.; Eder, B. Fully coupled "online" chemistry within the WRF model. Atmos. Environ. 2005, 39, 6957-6975. [CrossRef]

27. Werner, M.; Kryza, M.; Guzikowski, J. Can data assimilation of surface PM2.5 and Satellite AOD improve WRF-Chem Forecasting? A case study for two scenarios of particulate air pollution episodes in Poland. Remote Sens. 2019, 11, 1-16. [CrossRef]

28. Chen, F.; Dudhia, J. Coupling an Advanced Land Surface-Hydrology Model with the Penn State-NCAR MM5 Modeling System. Part I: Model Implementation and Sensitivity. Mon. Weather Rev. 2001, 129, 569-585. [CrossRef]

29. Hong, S.-Y.; Noh, Y.; Dudhia, J. A New Vertical Diffusion Package with an Explicit Treatment of Entrainment Processes. Mon. Weather Rev. 2006, 134, 2318-2341. [CrossRef]

30. Iacono, M.J.; Delamere, J.S.; Mlawer, E.J.; Shephard, M.W.; Clough, S.A.; Collins, W.D. Radiative forcing by long-lived greenhouse gases: Calculations with the AER radiative transfer models. J. Geophys. Res. 2008, 113, D13103. [CrossRef]

31. Morrison, H.; Thompson, G.; Tatarskii, V.; Morrison, H.; Thompson, G.; Tatarskii, V. Impact of Cloud Microphysics on the Development of Trailing Stratiform Precipitation in a Simulated Squall Line: Comparison of One- and Two-Moment Schemes. Mon. Weather Rev. 2009, 137, 991-1007. [CrossRef]

32. Ahmadov, R.; McKeen, S.A.; Robinson, A.L.; Bahreini, R.; Middlebrook, A.M.; de Gouw, J.A.; Meagher, J.; Hsie, E.-Y.; Edgerton, E.; Shaw, S.; et al. A volatility basis set model for summertime secondary organic aerosols over the eastern United States in 2006. J. Geophys. Res. Atmos. 2012, 117, D06301. [CrossRef]

33. Werner, M.; Kryza, M.; Wind, P. High resolution application of the EMEP MSC-W model over Eastern Europe-Analysis of the EMEP4PL results. Atmos. Res. 2018, 212, 6-22. [CrossRef] 
34. Kuenen, J.J.P.; Visschedijk, A.J.H.; Jozwicka, M.; Denier van der Gon, H.A.C. TNO-MACC_II emission inventory; a multi-year (2003-2009) consistent high-resolution European emission inventory for air quality modelling. Atmos. Chem. Phys. 2014, 14, 10963-10976. [CrossRef]

35. R Core Team R: A Language and Environment for Statistical Computing 2019. Available online: https: //www.r-project.org/ (accessed on 3 July 2020).

36. Bieser, J.; Aulinger, a.; Matthias, V.; Quante, M.; Builtjes, P. SMOKE for Europe - adaptation, modification and evaluation of a comprehensive emission model for Europe. Geosci. Model Dev. Discuss. 2010, 3, 949-1007. [CrossRef]

37. Guenther, A.; Karl, T.; Harley, P.; Wiedinmyer, C.; Palmer, P.I.; Geron, C. Estimates of global terrestrial isoprene emissions using MEGAN (Model of Emissions of Gases and Aerosols from Nature). Atmos. Chem. Phys. 2006, 6, 3181-3210. [CrossRef]

38. Wiedinmyer, C.; Akagi, S.K.; Yokelson, R.J.; Emmons, L.K.; Al-Saadi, J.A.; Orlando, J.J.; Soja, A.J. The Fire INventory from NCAR (FINN): A high resolution global model to estimate the emissions from open burning. Geosci. Model Dev. 2011, 4, 625-641. [CrossRef]

39. Emery, C.; Liu, Z.; Russell, A.G.; Odman, M.T.; Yarwood, G.; Kumar, N. Recommendations on statistics and benchmarks to assess photochemical model performance. J. Air Waste Manag. Assoc. 2017, 67, 582-598. [CrossRef]

40. Willmott, C.J. Some comments on the evaluation of economic forecasts. Bull. Am. Meteorol. Soc. 1982, 63, 1309-1313. [CrossRef]

41. Castell, N.; Stein, A.F.; Mantilla, E.; Salvador, R.; Millán, M. Evaluation of the use of photochemical indicators to assess ozone-NOx-VOC sensitivity in the Southwestern Iberian Peninsula. J. Atmos. Chem. 2009, 63, 73-91. [CrossRef]

42. Sillman, S.; He, D.; Pippin, M.R.; Daum, P.H.; Imre, D.G.; Kleinman, L.I.; Lee, J.H.; Weinstein-Lloyd, J. Model correlations for ozone, reactive nitrogen, and peroxides for Nashville in comparison with measurements: Implications for $\mathrm{O}_{3}$-NOx-hydrocarbon chemistry. J. Geophys. Res. Atmos. 1998, 103, 22629-22644. [CrossRef]

43. Juda-Rezler, K.; Reizer, M.; Maciejewska, K.; Błaszczak, B.; Klejnowski, K. Characterization of atmospheric PM2.5 sources at a Central European urban background site. Sci. Total Environ. 2020, 713, 136729. [CrossRef] [PubMed]

44. Adamiec, E.; Jarosz-Krzemińska, E.; Wieszała, R. Heavy metals from non-exhaust vehicle emissions in urban and motorway road dusts. Environ. Monit. Assess. 2016, 188,1-11. [CrossRef]

45. Dore, A.J.; Kryza, M.; Hall, J.R.; Hallsworth, S.; Keller, V.J.D.; Vieno, M.; Sutton, M.A. The influence of model grid resolution on estimation of national scale nitrogen deposition and exceedance of critical loads. Biogeosciences 2012, 9, 1597-1609. [CrossRef] 